\title{
Growth performance and nutrient utilisation as influenced in pigs by microbial phytase and vitamin $E$ supplementation to a diet of high oxidative capacity
}

\author{
Stefan Gebert*, Giuseppe Bee, Hans Peter Pfirter, Caspar Wenk
}

Institute of Animal Sciences, Nutrition Biology, Swiss Federal Institute of Technology Zurich, 8092 Zurich, Switzerland

(Received 25 February 1998; accepted 8 July 1998)

\begin{abstract}
In the first of two experiments carried out with growing-finishing pigs, 40 barrows were kept from 25 to $104 \mathrm{~kg}$ body weight (BW). In the second experiment, 24 pigs were kept from 75 to $104 \mathrm{~kg} \mathrm{BW}$. The pigs were fed either a barley-maize-based diet $(C)$, or the same diet supplemented with either 1200 PTU phytase $(P h)$ or $200 \mathrm{mg} \alpha$-tocopheryl acetate $\cdot \mathrm{kg}^{-1}(E)$, or both $(P h E)$ in order to assess the effect of microbial phytase and vitamin $E$ on growth performance (experiment 1 ) and the precaecal digestibility of $\mathrm{P}, \mathrm{Ca}, \mathrm{Mg}, \mathrm{Fe}, \mathrm{Cu}, \mathrm{Zn}$, crude fat and fatty acids (experiment 2 ). $P h$ supplementation improved mean daily weight gain $(P<0.05)$ and reduced the feed conversion ratio ( $\mathrm{kg}$ feed $\cdot \mathrm{kg}^{-1}$ weight gain, $P<0.01$ ). Supplementation with $\alpha$-tocopherol (vitamin E) did not affect growth performance. $P h$ inclusion improved precaecal digestibility of $\mathrm{P}(P<0.001)$ and reduced that of $\mathrm{Zn}(P<0.05)$. The $\alpha$-tocopherol addition improved $(P<0.01)$ the digestibility of $\mathrm{Zn}$, whereas the $\alpha$-tocopherol digestibility was not affected. The precaecal digestibility of total lipids and the saturated, monounsaturated and polyunsaturated fatty acids were reduced $(P<0.05$ to 0.001$)$ by $P h$ supplementation. The combined addition of $P h$ and $E$ improved the digestibility of dietary fatty acids. We concluded that dietary phytase in pig diets susceptible to lipid oxidation demands an additional vitamin $\mathrm{E}$ supplementation in order to avoid detrimental effects on fat digestibility. (@) Elsevier / Inra)
\end{abstract}

pigs / phytase / vitamin E / fatty acids / performance / digestibility

Résumé - Performances de croissance et utilisation des nutriments chez le porc sous l'influence de phytase microbienne et d'un supplément en vitamine $E$. Deux essais ont été réalisés avec des pores en fin de croissance : dans le premier essai quarante porcs castrés ont été élevés de 25 à $104 \mathrm{~kg}$ de poids vif (PV); dans le second, vingt-quatre castrats de 75 à $104 \mathrm{~kg}$ de PV. L'alimentation des porcs consistait soit en une ration à base d'orge et de mais $(C)$, soit en la même ration supplémentée avec de la phytase à 1200 U.P. $(P h)$ ou $200 \mathrm{mg}$ d'acétate d' $\alpha$-tocophérol $(E)$ ou les deux $(P h E)$, afin de

* Correspondence and reprints

Tel.: 41163232 75; fax: 4116321128 ; e-mail: stefan.gebert@inw.agrl.ethz.ch 
déterminer les effets de la phytase microbienne et de la vitamine $E$ sur les performances de croissance (essai 1), ainsi que sur la digestibilité précæcale du $\mathrm{P}, \mathrm{Ca}, \mathrm{Mg}, \mathrm{Fe}, \mathrm{Cu}, \mathrm{Zn}$, de la matière grasse et des acides gras (essai 2). Le gain journalier moyen à été plus élevé $(p<0,05)$ et l'indice de consommation a été plus faible $(p<0,01)$ pour les porcs nourris avec les régimes additionnés de phytase. La vitamine $\mathrm{E}$ ( $\alpha$-tocophérol) dans la ration n'a pas eu d'effet sur les performances de croissance. La digestibilité précæcale du $\mathrm{P}$ a été augmentée $(p<0,001)$ et celle du Zn réduite $(p<0,05)$ à la suite de l'incorporation de phytase. L'addition de vitamine $\mathrm{E}$ a augmenté la digestibilité du $\mathrm{Zn}$, sans affecter la digestibilité de l' $\alpha$-tocophérol. La digestibilité précæcale des matières grasses totales, des acides gras saturés, monosaturés et polyinsaturés a été réduite $(p<0,05$ à 0,001$)$ par une supplémentation de phytase microbienne dans l'alimentation. L'addition combinée de vitamine $E$ et de phytase $(P h E)$ a augmenté la digestibilité des acides gras du régime alimentaire. L'inclusion de phytase dans la ration de porcs, dans le cas d'une ration susceptible à l'oxydation des lipides, nécessite donc l'addition de vitamine E supplémentaire, ceci afin d'éviter des effets négatifs sur la digestibilité des matières grasses. (C Elsevier / Inra)

\section{porcs / phytase / vitamine E / acides gras / performances / digestibilité}

\section{INTRODUCTION}

In numerous reports it is well documented that microbial-derived phytase in diets for pigs considerably increases the bioavailibility of various minerals and trace elements bound in the phytate complexes of dietary plant seeds $[8,17,29]$. The evidence for the nutritional significance and physiological and ecological importance of microbial phytase for monogastric animals has been given.

It is well known that free radicals, able to initiate lipid oxidation, can be formed in the presence of trace elements. For instance, free iron ions $\left(\mathrm{Fe}^{2+/ 3+}\right)$ are able to catalyse lipid peroxidation [24]. Nevertheless, there is only little information regarding whether minerals such as iron, copper and zinc hydrolysed from phytic acid complexes by exogenous phytase can influence the digestibility of nutrients that are very susceptible to oxidation as unsaturated fatty acids. Gebert et al. [8] found a significant reduction in the precaecal digestibility of total fat and particularly unsaturated fatty acids by inclusion of phytase in the diet. Furthermore, the digestibility of fatty acids was increased by the addition of $\alpha$-tocopheryl acetate in diets supplemented with phytase. The results suggest some evidence that the inclusion of phytase in diets demands an additional supplementation of vitamin $\mathrm{E}$ ( $\alpha$-tocopherol) due to a higher oxidative load caused by an increased macro and micro mineral concentration in the digesta to avoid negative effects on fat digestibility.

The present study was aimed at testing the effects of vitamin $E$ on feeding a diet very susceptible to lipid oxidation with and without microbial phytase on precaecal fatty acid modification and the absorption of these and of minerals as well as on the performance of growing pigs.

\section{MATERIALS AND METHODS}

\subsection{Experimental design and animals}

In experiments 1 and 2, respectively ten and six castrated male pigs (Large White), weighing approximately 26 and $75 \mathrm{~kg}$, were randomly assigncd to each of four treatments (table $I$ ). The pigs were housed individually and grown until $104 \mathrm{~kg}$ body weight (BW). They were fed either a control diet $(C)$, or the same diet supplemented with either phytase $(P h)$ or vitamin $\mathrm{E}$ in the form of $\alpha$-tocopheryl acetate $(E)$, or both $(P h E)$. All pigs had ad libitum access to their feed and water. Two pigs in experiment 1 (treatment $E$ ) were removed at $60 \mathrm{~kg} \mathrm{BW}$ during the investigation 
Table I. Dietary treatments and composition of the basal diet.

\begin{tabular}{|c|c|c|c|c|}
\hline & \multicolumn{4}{|c|}{ Treatment } \\
\hline & $C$ & $P h$ & $E$ & PhE \\
\hline \multicolumn{5}{|l|}{ Supplements } \\
\hline Phytase $^{1}\left(\mathrm{PTU} \cdot \mathrm{kg}^{-1}\right)$ & - & 1200 & - & 1200 \\
\hline Vitamin $\mathrm{E}^{2}\left(\mathrm{mg} \cdot \mathrm{kg}^{-1}\right)$ & - & - & 200 & 200 \\
\hline \multicolumn{5}{|l|}{ Basal diet $(\%)$} \\
\hline Barley & \multicolumn{4}{|c|}{33.0} \\
\hline Maize & \multicolumn{4}{|c|}{27.7} \\
\hline Soybean meal ( $44 \%$ crude protein) & \multicolumn{4}{|c|}{11.0} \\
\hline Sunflower meal (undehulled) & \multicolumn{4}{|c|}{11.0} \\
\hline Potato protein & \multicolumn{4}{|c|}{5.2} \\
\hline Safflower oil & \multicolumn{4}{|c|}{7.3} \\
\hline Lysine- $\mathrm{HCl}$ & \multicolumn{4}{|c|}{0.2} \\
\hline Ground limestone & \multicolumn{4}{|c|}{1.6} \\
\hline Salt & \multicolumn{4}{|c|}{0.5} \\
\hline Celite 545 & \multicolumn{4}{|c|}{1.5} \\
\hline Vitamin-premix (based on maize) $^{3}$ & \multicolumn{4}{|c|}{1.0} \\
\hline
\end{tabular}

' $240 \mathrm{mg}$ Natuphos ( $\geq 5000$ PTU $\cdot \mathrm{g}^{-1}$ ) per $\mathrm{kg}$ from BASF, D - Ludwigshafen; ${ }^{2} 400 \mathrm{mg}$ Rovimix E - $50 \mathrm{SD}$ ( $500 \mathrm{mg} \alpha$-tocopheryl acetate $\cdot \mathrm{g}^{-1}$ ) per $\mathrm{kg}$ from $\mathrm{F}$. Hoffmann - La Roche AG, $\mathrm{CH}$ - Basel; ${ }^{3}$ per $\mathrm{kg}$ feed: vitarnin B2, $4 \mathrm{mg}$; vitamin B6, $4 \mathrm{mg}$; vitamin A, $2000 \mathrm{IU}$; vitamin D3, $500 \mathrm{IU}$; Ca-Pantothenate, $15 \mathrm{mg}$; Niacin, $20 \mathrm{mg}$; $P h \times E$ means interaction of $P h$ and $E$.

because of sudden symptoms of oedema disease. Therefore, they were not included in the data analysis of growth performance.

\subsection{Diets}

The diets were cereal based, composed mainly of barley, maize, as well as extracted soybean meal, extracted sunflower meal and potato protein (table $I$ ). The intended susceptibility to lipid oxidation was obtained by using safflower oil as a fat source, high in unsaturated fatty acids with its low content of native $\alpha$-tocopherol. Celite 545 (acid-washed diatomaceous earth), a nutritionally inert substance, was added to the diet to increase the level of $4 \mathrm{~N}-\mathrm{HCl}$ insoluble ash (AIA) and reduce variability in the analysis. The microbial phytase was oversupplemented by $20 \%$ (table I), because the diets were steam-pelleted at $65^{\circ} \mathrm{C}$, and should contain a final concentration of 1000 units (PTU) $\mathrm{kg}^{-1}$. The recommended total phosphorus concentration in diets for growing pigs is $0.3-0.4 \mathrm{~g} \cdot \mathrm{MJ}^{-1}$ digestible energy (DE) [21]. In the present investigation, no additional inorganic phosphorus was supplied to the diets, because a low phosphorus content of less than $0.3 \mathrm{~g} \cdot \mathrm{MJ}^{-1} \mathrm{DE}$ was desired. The added premix contained the essential vitamins on dietary recommended levels [21], as shown in table l, without vitamin $E$ and supplemental trace elements.

As expected, the analysed nutrient, the mineral content and the fatty acid profile of the four diets were almost identical (table II). All diets contained the recommended levels of amino acids to allow good growth performance. The calculated content DE was $15.4 \mathrm{MJ} \cdot \mathrm{kg}^{-1} \mathrm{DM}$. The diets were adequate in $\mathrm{P}, \mathrm{Mg}, \mathrm{Fe}$ and $\mathrm{Cu}$, whereas the $\mathrm{Ca}$ content was rather high and the $\mathrm{Zn}$ content was below the recommendation for growing pigs [21]. Because of the relatively high quantity of safflower oil, the mean crude fat content exceeded $100 \mathrm{~g} \cdot \mathrm{kg}^{-1} \mathrm{DM}$, and the fatty acid profiles consisted of high values of unsaturated fatty acids, especially oleic and linoleic acid. The mean $\alpha$-tocopherol content in treatment $E$ and $P h E$ was $250 \mathrm{mg} \cdot \mathrm{kg}^{-1} \mathrm{DM}$, and the phytase activity of diet $P h$ and $P h E$ was about $1000 \mathrm{PTU} \cdot \mathrm{kg}^{-1}$ DM. Both supplements corresponded to the estimated levels. 
Table II. Analysed nutrient content, energy and mineral content and the fatty acid profile of the experimental diets.

\begin{tabular}{|c|c|c|c|c|}
\hline & \multicolumn{4}{|c|}{ Treatment } \\
\hline & $C$ & $P h$ & E & $P h E$ \\
\hline \multicolumn{5}{|c|}{ Nutrient content per $k g$ dry matter } \\
\hline Crude ash, CA (g) & 73 & 73 & 76 & 71 \\
\hline Crude protein, CP (g) & 188 & 191 & 193 & 191 \\
\hline Crude fat, CL $(\mathrm{g})$ & 121 & 117 & 112 & 114 \\
\hline Crude fibre, CF (g) & 65 & 62 & 65 & 60 \\
\hline Gross energy (MJ) & 20.1 & 20.1 & 20.0 & 20.0 \\
\hline $\mathrm{DE}^{1}(\mathrm{MJ})$ & 15.3 & 15.4 & 15.3 & 15.5 \\
\hline$\alpha$-tocopherol (mg) & 54 & 57 & 243 & 258 \\
\hline Phytase activity (PTU) & $<150$ & 1025 & $<150$ & 1003 \\
\hline Phosphorus (g) & 3.9 & 4.3 & 4.2 & 4.3 \\
\hline Calcium $(\mathrm{g})$ & 9.5 & 9.3 & 9.1 & 8.3 \\
\hline Magnesium (g) & 2.1 & 2.1 & 2.0 & 2.0 \\
\hline Iron $(\mathrm{mg})$ & 188 & 169 & 166 & 159 \\
\hline Copper (mg) & 10 & 10 & 10 & 10 \\
\hline Zinc $(\mathrm{mg})$ & 44 & 36 & 36 & 41 \\
\hline Total fatty acids (g) & 103 & 101 & 94 & 96 \\
\hline \multicolumn{5}{|c|}{ Fatty acid profile in $\%$ of total fatty acids ${ }^{2}$} \\
\hline$\Sigma$ SFA & 12.9 & 12.8 & 12.8 & 12.9 \\
\hline $\mathrm{C}_{160}$ & 9.6 & 9.5 & 9.5 & 9.6 \\
\hline $\mathrm{C}_{18: 0}$ & 2.8 & 2.8 & 2.7 & 2.7 \\
\hline$\Sigma$ MUFA & 20.9 & 20.3 & 20.7 & 20.8 \\
\hline $\mathrm{C}_{18: 1(1)-9}$ & 19.4 & 19.2 & 19.5 & 19.5 \\
\hline$\Sigma$ PUFA & 66.2 & 66.9 & 66.4 & 66.3 \\
\hline $\mathrm{C}_{18: 2(0)-6}$ & 64.5 & 65.2 & 64.8 & 64.7 \\
\hline $\mathrm{C}_{18: 3(\omega-3)}^{18: 20-6}$ & 1.1 & 1.1 & 1.1 & 1.1 \\
\hline
\end{tabular}

' Digestible energy, calculated from crude nutricnts by regression: $\mathrm{DE}=19.0 * \mathrm{CP}+33.5 * \mathrm{CL}-21.2 * \mathrm{CF}+16.6$

$*$ NFE; ${ }^{2}$ SFA: satturated fatty acids; MUFA: monounsaturated fatty acids; PUFA: polyunsaturated fatty acids; $\Sigma=$ sum

\subsection{Sampling procedure}

In experiment 1 , the individual $\mathrm{BW}$ and feed intake data of the pigs were recorded weekly. The animals were slaughtered in the abattoir of the 'Prüfanstalt des Schweizerischen Verbandes für Mast- und Schlachtleistungsprüfung beim Schwein (MLP)'. Carcass dissection was assessed according to MLP regulations. The results were reported in another paper [9].

In order to collect samples of digesta from the intestinal tract, the animals from experiment
2 were slaughtered according to the method described by Hadorn [11]. Immediately after killing, digesta samples were taken from the caecum, frozen with liquid nitrogen and stored at $-20{ }^{\circ} \mathrm{C}$ until the analytical procedure was performed.

\subsection{Analytical methods}

The caecal digesta samples were freeze-dried and ground in a centrifugal mill (Retsch ZM 1 
Arlesheim, Switzerland) using a titan piston and titan sieve $(0.5 \mathrm{~mm})$. The standard Weende procedure was used to determine the nutrients in feed as dry matter (DM), crude ash (CA), crude fibre (CF) and crude protein (CP). Crude fat (CL) was analysed according to Winter [30]. The determination of the gross energy (GE) content was performed with an anisothermic calorimeter (IKA-Kalorimetersystem C 700 T, Heitersheim, Germany). The minerals $\mathrm{P}, \mathrm{Ca}, \mathrm{Mg}, \mathrm{Fe}, \mathrm{Cu}$ and $\mathrm{Zn}$ were analysed by atomic absorption spectrometry (Perkin Elmer AG Rotkreuz, Switzerland) at the Swiss Federal Research Station for Animal Production (RAP, Posicux, Switzerland) following the validated procedure $[20,22]$.

The $\alpha$-tocopherol concentration was determined by the high performance liquid chromatography (HPLC) method of Rettenmaier and Schüep [23]. The lipid extraction was followed by the method of Winter [30] as modified by Prabucki [12] using chloroform/methanol (2:1, $\mathrm{v} / \mathrm{v}$ ). Prior to extraction, the digesta samples were adjusted to $\mathrm{pH} 2$ by means of $37 \% \mathrm{HCl}$. The extracted lipids were transformed to their methyl esters by using sodium hydroxide and boron trifluoride, both in methanol [15]. The fatty acid methyl esters (FAMEs) were analysed using a Hewlett Packard model HP 5860 A gas chromatograph, equipped with a flame ionisation detector (FID). The FAMEs were separated on a $30 \mathrm{~m} * 0.32 \mathrm{~mm}$ Supelcowax $10 \mathrm{CB}$ fused-silica capillary column using the following time programme: $3 \mathrm{~min}$ at $175^{\circ} \mathrm{C}$, then to $230^{\circ} \mathrm{C}$ with $3^{\circ} \mathrm{C} \cdot \mathrm{min}^{-1}$. The injector and detector temperature were maintained at $250^{\circ} \mathrm{C}$; the carrier gas was $\mathrm{N}_{2}$. FAMEs were quantified by an external standard (C13:0).

The digestibility was estimated by means of the indicator method [19], using AIA as indicator.

\subsection{Statistical analysis}

Experimental data were analysed statistically by using Statgraphics plus for Windows version 2.I [27] and treated by multifactor analysis of variance (ANOVA) with phytase and vitamin $\mathrm{E}$ level as factors. The results are given as means and standard deviations. When significant $(P<0.05)$ dependent variable effects were found, mean values were separated using Bonferroni's multiple range test (ns: not significant; $* P<0.05$; ** $P<0.01$; **** $P<0.001$ ).

\section{RESULTS AND DISCUSSION}

\subsection{Effect of dietary treatments on growth performance}

Under the experimental condition of ad libitum feeding, there was a significant influence of phytase supplementation on days in experiment, daily body weight gain (DWG) and feed conversion ratio (FCR) (table III). Daily feed intake (DFI) was not affected by $P h$ supplementation. The inclusion of dietary vitamin $E$ to the diets did not significantly influence growth parameters. $P h$ pigs grew faster $\left(73 \mathrm{~g} \cdot \mathrm{day}^{-1}\right)$, and the FCR was lower $(P<0.01)$ than in the pigs that received no phytase, because the days in experiment were also reduced $(P<0.01)$. As a consequence, the FCR was significantly lower for animals of treatments $P h$ and $P h E$ than for those of treatment $E$. Since phytic acid is also able to form complexes with protein [10], an enhanced protein digestibility could be expected by the inclusion of phytase and therefore an expected influence on growth performance. In conclusion, the effectiveness of microbial phytase for pigs has been shown by the responses in performance.

The improvement in performance results of pigs due to phytase supplementation has been reported previously by Mroz et al. [16] and Cromwell et al. [4]. In their studies inclusion of dietary phytase up to $1000 \mathrm{PTU} \cdot \mathrm{kg}^{-1}$ feed in low phosphorus diets increased DFI and consequently improved DWG and decreased FCR.

In agreement with our results, no effect on growth parameters due to supplementation of diets with vitamin $E$ has been reported in other investigations with growing pigs $[3,8,14]$. In contrast, Asghar et al. [1] reported a higher DWG and a better FCR in the early growth phase (first 4 weeks) of pigs fed a diet supplemented with $\alpha$-tocopheryl acetate (100 and $200 \mathrm{mg} \cdot \mathrm{kg}^{-1}$ feed). This controversy may be explained by Bieri et al. [2], who suggested that $200 \mathrm{mg}$ vita$\min \mathrm{E} \cdot \mathrm{kg}^{-1}$ feed may be more than the optimal amount needed at those body weights 
Table III. Effect of phytase and vitamin E supplementation on growth performance of pigs (experiment 1).

\begin{tabular}{|c|c|c|c|c|c|c|c|}
\hline \multirow[b]{2}{*}{ No. of pigs } & \multicolumn{7}{|c|}{ Treatment } \\
\hline & \multicolumn{2}{|c|}{$\begin{array}{l}C \\
10\end{array}$} & $\begin{array}{l}P h \\
10\end{array}$ & $E$ & 8 & \multicolumn{2}{|c|}{10} \\
\hline Body weight start (kg) & \multicolumn{2}{|c|}{$26.0(1.9)$} & $25.8(2.0)$ & \multicolumn{2}{|c|}{$25.9(1.7)$} & \multicolumn{2}{|c|}{$25.9(2.2)$} \\
\hline Body weight end $(\mathrm{kg})$ & \multicolumn{2}{|c|}{$103.6(4.3)$} & $104.0(2.4)$ & \multicolumn{2}{|c|}{$103.4(4.5)$} & \multicolumn{2}{|c|}{$102.9(3.0)$} \\
\hline Days in experiment (d) & \multicolumn{2}{|c|}{$112(8)$} & $103(12)$ & \multicolumn{2}{|c|}{$117(15)$} & \multicolumn{2}{|c|}{$104(12)$} \\
\hline Daily feed intake (kg) & \multicolumn{2}{|c|}{$2.07(0.10)$} & $2.12(0.17)$ & \multicolumn{2}{|c|}{$2.08(0.21)$} & \multicolumn{2}{|c|}{$2.12(0.14)$} \\
\hline Daily body weight gain $(\mathrm{g})$ & \multicolumn{2}{|c|}{$697(70)$} & $768(88)$ & \multicolumn{2}{|c|}{$676(102)$} & \multicolumn{2}{|c|}{$749(77)$} \\
\hline Feed conversion ratio $\left(\mathrm{kg} \cdot \mathrm{kg}^{-1}\right)$ & \multicolumn{2}{|c|}{$2.99^{\mathrm{ab}}(0.23)$} & $2.78^{\mathrm{a}}(0.22)$ & \multicolumn{2}{|c|}{$3.12^{\mathrm{b}}(0.31)$} & \multicolumn{2}{|c|}{$2.85^{\mathrm{a}}(0.26)$} \\
\hline \multirow[t]{2}{*}{ Factorial means } & \multicolumn{2}{|c|}{ Phytase } & \multicolumn{2}{|c|}{ Vitamin E } & \multicolumn{3}{|c|}{$P$ values } \\
\hline & - & + & - & + & $P h$ & $E$ & $P h \times E$ \\
\hline Body weight start (kg) & 25.9 & 25.9 & 25.9 & 25.9 & ns & ns & ns \\
\hline Body weight end $(\mathrm{kg})$ & 103.6 & 103.6 & 103.9 & 103.9 & ns & ns & $\mathrm{ns}$ \\
\hline Days in experiment (d) & 114 & 103 & 107 & 110 & $* *$ & ns & ns \\
\hline Daily feed intake (kg) & 2.08 & 2.12 & 2.10 & 2.10 & ns & ns & $\mathrm{ns}$ \\
\hline Daily body weight gain (g) & 686 & 759 & 732 & 712 & * & ns & $\mathrm{ns}$ \\
\hline Feed conversion ratio $\left(\mathrm{kg} \cdot \mathrm{kg}^{-1}\right)$ & 3.05 & 2.82 & 2.89 & 2.98 & $* *$ & $\mathrm{~ns}$ & $\mathrm{~ns}$ \\
\hline
\end{tabular}

Mean values with different superscripts in a row are significantly different $(P<0.05)$.

and thus reduces the intestinal absorption of vitamin A, which he calls an important growth-promoting vitamin.

\subsection{Effect of dietary treatments on precaecal mineral digestibility}

The most pronounced effect $(P<0.001)$ of the supplementary phytase concerns the precaecal digestibility of phosphorus, which increased on average by 0.157 or $46 \%$ (table IV). Surprisingly, the precaecal digestibility of zinc was reduced. However, the $\alpha$-tocopherol supplementation had a positive effect on zinc digestibility. Calcium, magnesium, iron and copper digestibility was not affected by the $P h$ nor the $E$ supplementation.

Negative values in digestibility, as obtained for copper in treatment $P h$, can be explained by the exocrine secretion of gas- tric, biliary and pancreatic juices. Evaluating exogenous phytase efficacy over the total tract (faeces) digestibility, the phosphorus digestibility on factorial basis was 0.521 for the phytase-supplemented groups and 0.336 for the non-phytase-supplemented groups (data not shown) and were similar to the results in our recently completed study [8]. Evidently, in both studies, the precaecal digestibility of phosphorus indicated no significant difference from its faecal digestibility. These results coincide with those of Jongbloed et al. [13] and Mroz et al. [16], who by comparing faecal digestibility and the ileal digestibility, described that the net movement of total phosphorus into the large intestine was relatively small (up to 4.4 percentage units).

The values found for the precaecal digestibility of $\mathrm{Ca}, \mathrm{Mg}, \mathrm{Fe}, \mathrm{Cu}$ and $\mathrm{Zn}$ were similar to our previous study (unpublished data) and were different from their faecal digestibilities. The results indicate that, in 
Table IV. Treatment effects on precaecal digestibility of $\mathrm{P}, \mathrm{Ca}, \mathrm{Mg}, \mathrm{Fe}, \mathrm{Cu}$ and $\mathrm{Zn}$ (experiment 2).

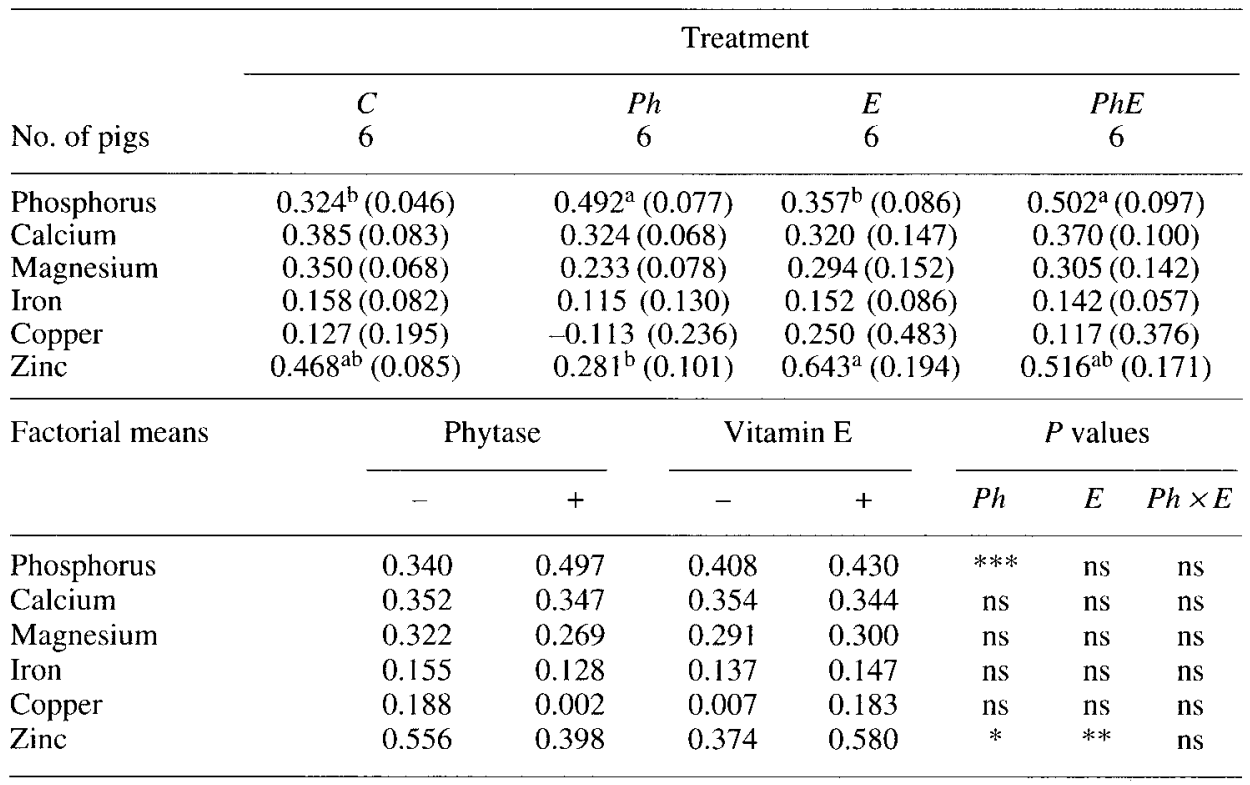

Mean values with different superscripts in a row are significantly different $(P<0.05)$.

contrast to $\mathbf{P}$, the digestibility of these minerals depends to a greater extent on the place of hydrolysis and/or absorption in the digestive tract. It was noted that endogenous excretion occurred as well. However, the degree of hydrolysis of the phytic acid complexes by $P h$ inclusion in different sections of the gastrointestinal tract of pigs has not yet been studied. Nevertheless, contradictory reports concerning intestinal absorption or excretion of some minerals were presented by Partridge [18], Drochner [6], Den Hartog et al. [5] and Rodehutscord et al. [25]. However, these disagreements probably emphasise the complexity of this subject.

\subsection{Effect of dietary treatments on precaecal digestibility of $\alpha$-tocopherol, fat and fatty acids}

From the results presented in table $V$, there is evidence of a higher $\alpha$-tocopherol concentration in the caecal digesta of pigs fed diets $E$ and $P h E$ than in pigs fed diets $C$ and $P h$. There was also a significant interaction between the two supplements. The digestibility of $\alpha$-tocopherol was not affected by the dietary $\alpha$-tocopherol level or phytase supplementation, respectively. The crude fat concentration in digesta and its digestibility were significantly influenced by $P h$ supplementation (table $V$ ). In treatment $P h$, the caecal crude fat concentration was highest and the precaecal digestibility lowest, respectively, compared to the other treatments. We assumed that the liberation of anions by the microbial phytase resulted in a higher degree of saponification of the crude fat. Thus, an increased crude fat content in the caecal digesta of the $P h$ treatment group was observed. This observation is also concomitant with the decrease in the digestibility of $\mathrm{Ca}$ and $\mathrm{Mg}$ (table $\mathrm{IV}$ ).

As previously reported [8], dietary $\alpha$-tocopherol concentration did not alter the 
Table V. Caecal concentration (per kg dry matter) of $\alpha$-tocopherol and crude fat and digestibility in digesta (experiment 2).

\begin{tabular}{|c|c|c|c|c|c|c|c|}
\hline \multirow[b]{2}{*}{ No. of pigs } & \multicolumn{7}{|c|}{ Treatment } \\
\hline & $\begin{array}{l}C \\
6\end{array}$ & \multicolumn{2}{|c|}{$P h$} & \multicolumn{2}{|l|}{$E$} & \multicolumn{2}{|c|}{$P h E$} \\
\hline \multicolumn{8}{|l|}{$\alpha$-tocopherol } \\
\hline Concentration (mg) & $69^{\mathrm{c}}(20)$ & \multirow{2}{*}{\multicolumn{2}{|c|}{$\begin{array}{c}70^{\mathrm{C}}(20) \\
0.580(0.105)\end{array}$}} & \multicolumn{2}{|c|}{$\begin{array}{c}365^{b}(126) \\
0.626(0.142)\end{array}$} & \multicolumn{2}{|c|}{$540^{\mathrm{a}}(130)$} \\
\hline Digestibility & $0.577(0.128)$ & & & \multicolumn{2}{|c|}{$0.626(0.142)$} & \multicolumn{2}{|c|}{$0.480(0.133)$} \\
\hline \multicolumn{8}{|l|}{ Crude fat } \\
\hline Concentration $(\mathrm{g})$ & \multirow{2}{*}{$\begin{array}{c}60^{\mathrm{b}}(7) \\
0.876^{\mathrm{a}}(0.017)\end{array}$} & \multirow{2}{*}{\multicolumn{2}{|c|}{$\begin{array}{c}92^{\mathrm{a}}(21) \\
0.811^{\mathrm{b}}(0.036)\end{array}$}} & \multirow{2}{*}{\multicolumn{2}{|c|}{$\begin{array}{c}69^{\mathrm{b}}(6) \\
0.849^{\mathrm{ab}}(0.020)\end{array}$}} & \multirow{2}{*}{\multicolumn{2}{|c|}{$\begin{array}{c}73^{\mathrm{ab}}(12) \\
0.844^{\mathrm{ab}}(0.027)\end{array}$}} \\
\hline Digestibility & & & & & & & \\
\hline \multirow[t]{2}{*}{ Factorial means } & \multicolumn{2}{|c|}{ Phytase } & \multicolumn{2}{|c|}{ Vitamin E } & \multicolumn{3}{|c|}{$P$ values } \\
\hline & - & + & - & + & $P h$ & $E$ & $P h \times E$ \\
\hline \multicolumn{8}{|l|}{$\alpha$-tocopherol } \\
\hline Concentration (mg) & 217 & 305 & 70 & 452 & $*$ & $* * *$ & $*$ \\
\hline Digestibility & 0.602 & 0.530 & 0.578 & 0.553 & ns & $\mathrm{ns}$ & ns \\
\hline \multicolumn{8}{|l|}{ Crude fat } \\
\hline Concentration $(\mathrm{g})$ & 64 & 83 & 76 & 71 & ** & ns & * \\
\hline Digestibility & 0.862 & 0.828 & 0.844 & 0.846 & $* *$ & ns & $*$ \\
\hline
\end{tabular}

Mean values with different superscripts in a row are significantly different $(P<0.05)$.

precaecal digestibility of $\alpha$-tocopherol. Elmadfa and Bosse [7] reported that the range of vitamin $\mathrm{E}$ absorption is inversely proportional to the level of vitamin $E$ in the feed, and the digestibility of vitamin $E$ is strongly influenced by nutrients such as fatty acids. However, the results on $\alpha$-tocopherol digestibility were comparable to those obtained by Schaarmann et al. [26] in pigs fed diets supplemented with vitamin $E$. The crude fat digestibility in the present study was higher than observed in our previous study due to a two-fold higher dietary concentration of the polyenic fatty acids in this study. It has long been known that many factors such as the mean chain length, degree of esterification or the ratio of saturated to unsaturated fatty acids influence the fat digestibility [28].

The precaecal digestibility of the fatty acids was significantly influenced by $P h$ supplementation (table VI). The lowest digestibility values were found for diet $P h$ and the highest for diet $C(P<0.05)$, respectively. Significant interactions between $P h$ and $E$ occurred for total lipids, saturated and monoenic fatty acids. Total lipids are the sum of all chromatographically analysed fatty acids, whereas the crude fat (table $V$ ) was measured by weight analysis, and thus, explains the different values. The digestibility of the saturated and the monounsaturated fatty acids was significantly lower by 0.065 $(8 \%)$ and $0.074(8 \%)$, respectively, in diet $P h$ than in diet $E$. On tendency, similar results were obtained for the digestibility of the polyunsaturated fatty acids.

As expected, stearic acid $\left(\mathrm{C}_{18: 0}\right)$ was digested at a lower rate than palmitic acid $\left(\mathrm{C}_{16: 0}\right)$ due to its longer carbon chain. Overall, in treatment $P h$ the fatty acid digestibility was always the lowest and in treatment $C$ 
Table VI. Treatment effects on precaecal digestibility of fatty acids (experiment 2).

\begin{tabular}{|c|c|c|c|c|c|c|c|}
\hline \multirow[b]{2}{*}{ No. of pigs } & \multicolumn{7}{|c|}{ Treatment } \\
\hline & $\begin{array}{l}C \\
6\end{array}$ & \multicolumn{2}{|c|}{$\begin{array}{c}P h \\
6\end{array}$} & $\begin{array}{l}E \\
6\end{array}$ & \multicolumn{3}{|c|}{$\begin{array}{c}P h E \\
6\end{array}$} \\
\hline$\Sigma$ Lipids & $0.948^{\mathrm{a}}(0.010)$ & \multicolumn{2}{|c|}{$0.881^{b}(0.041)$} & $0.923^{\mathrm{ab}}(0.026)$ & \multicolumn{3}{|c|}{$0.916^{\mathrm{ab}}(0.015)$} \\
\hline $\begin{array}{c}\Sigma \text { SFA } \\
C_{16: 0} \\
C_{18: 0}\end{array}$ & $\begin{array}{l}0.898^{\mathrm{a}}(0.017) \\
0.925^{\mathrm{a}}(0.012) \\
0.863^{\mathrm{a}}(0.039)\end{array}$ & \multicolumn{2}{|c|}{$\begin{array}{l}0.760^{\mathrm{c}}(0.048) \\
0.833^{\mathrm{b}}(0.061) \\
0.649^{\mathrm{b}}(0.066)\end{array}$} & $\begin{array}{c}0.884^{\mathrm{ab}}(0.028) \\
0.713^{\mathrm{b}}(0.053)\end{array}$ & \multicolumn{3}{|c|}{$\begin{array}{c}0.883^{\mathrm{ab}}(0.020) \\
0.719^{\mathrm{b}}(0.102)\end{array}$} \\
\hline $\begin{array}{l}\Sigma \text { MUFA } \\
\text { C }_{18: 1 \omega-9}\end{array}$ & $\begin{array}{l}0.939^{\mathrm{a}}(0.011) \\
0.943^{\mathrm{a}}(0.010)\end{array}$ & \multicolumn{2}{|c|}{$\begin{array}{l}0.828^{\mathrm{b}}(0.058) \\
0.841^{\mathrm{b}}(0.059)\end{array}$} & $\begin{array}{l}0.902^{\mathrm{a}}(0.039) \\
0.909^{\mathrm{a}}(0.038)\end{array}$ & \multicolumn{3}{|c|}{$\begin{array}{c}0.894^{\mathrm{a}}(0.021) \\
0.901^{\mathrm{ab}}(0.020)\end{array}$} \\
\hline $\begin{array}{l}\Sigma \text { PUFA } \\
\text { C }_{18: 2 \omega-6} \\
C_{18: 3 \omega-3} \\
\end{array}$ & $\begin{array}{c}0.960^{\mathrm{a}}(0.008) \\
0.963^{\mathrm{a}}(0.008) \\
0.931(0.006)\end{array}$ & \multicolumn{2}{|c|}{$\begin{array}{c}0.927^{\mathrm{b}}(0.025) \\
0.931^{\mathrm{b}}(0.025) \\
0.910(0.013)\end{array}$} & $\begin{array}{c}0.947^{\mathrm{ab}}(0.024) \\
0.951^{\mathrm{ab}}(0.023) \\
0.926(0.018)\end{array}$ & \multicolumn{3}{|c|}{$\begin{array}{c}0.941^{\mathrm{ab}}(0.011) \\
0.945^{\mathrm{ab}}(0.011) \\
0.920(0.015)\end{array}$} \\
\hline \multirow[t]{2}{*}{ Factorial means } & \multicolumn{2}{|c|}{ Phytase } & \multicolumn{2}{|c|}{ Vitamin E } & \multicolumn{3}{|c|}{$P$ values } \\
\hline & - & + & - & + & $P h$ & $E$ & $P h \times E$ \\
\hline$\Sigma$ Lipids & 0.936 & 0.898 & 0.915 & 0.919 & $* *$ & ns & $*$ \\
\hline $\begin{array}{l}\sum \text { SFA } \\
C_{16: 0} \\
C_{18: 0}\end{array}$ & $\begin{array}{l}0.861 \\
0.905 \\
0.788\end{array}$ & $\begin{array}{l}0.787 \\
0.858 \\
0.684\end{array}$ & $\begin{array}{l}0.829 \\
0.879 \\
0.756\end{array}$ & $\begin{array}{l}0.820 \\
0.883 \\
0.716\end{array}$ & $\begin{array}{l}* * * \\
* * \\
* *\end{array}$ & $\begin{array}{l}\mathrm{ns} \\
\mathrm{ns} \\
\mathrm{ns}\end{array}$ & $\begin{array}{l}* * * \\
* * \\
* *\end{array}$ \\
\hline $\begin{array}{l}\Sigma \text { MUFA } \\
\text { C }_{18: 10-9}\end{array}$ & $\begin{array}{l}0.921 \\
0.926\end{array}$ & $\begin{array}{l}0.861 \\
0.871\end{array}$ & $\begin{array}{l}0.884 \\
0.892\end{array}$ & $\begin{array}{l}0.898 \\
0.905\end{array}$ & $\begin{array}{l}* * * \\
* *\end{array}$ & $\begin{array}{l}\text { ns } \\
\text { ns }\end{array}$ & $\begin{array}{l}* * \\
* *\end{array}$ \\
\hline $\begin{array}{l}\Sigma \text { PUFA } \\
C_{18: 2 \omega-6} \\
C_{18: 3 \omega-3}\end{array}$ & $\begin{array}{l}0.954 \\
0.957 \\
0.928\end{array}$ & $\begin{array}{l}0.934 \\
0.938 \\
0.915\end{array}$ & $\begin{array}{l}0.944 \\
0.945 \\
0.920\end{array}$ & $\begin{array}{l}0.944 \\
0.948 \\
0.923\end{array}$ & $\begin{array}{l}* \\
* \\
*\end{array}$ & $\begin{array}{l}\mathrm{ns} \\
\mathrm{ns} \\
\mathrm{ns}\end{array}$ & $\begin{array}{l}\text { ns } \\
\text { ns } \\
\text { ns }\end{array}$ \\
\hline
\end{tabular}

SFA: saturated fatty acids; MUFA: monounsaturated fatty acids; PUFA: polyunsaturated fatty acids; $\Sigma=$ sum. Mean values with different superscripts in a row are significantly different $(P<0.05)$.

and $E$ the highest, whereas treatment $P h E$ was in between, thus confirming recent data [9]. In the present study the effects were more pronounced as a consequence of the high dietary amount of unsaturated fatty acids and therefore those of higher susceptibility to lipid oxidation. The results indicate that the digestibility of the saturated as well as the unsaturated fatty acids was significantly affected by the phytase supplementation. We suggest that unsaturated fatty acids of the diet $P h$ might be oxidised by hydrolysed trace elements from phytic acid complexes or from formed free radicals due to the dietary $P h$ inclusion. This is largely due to the fact that the rate of lipid oxidation is mainly related to the polyenic fatty acids in the feed. On the other hand, the present results on fatty acid digestibility show elevated digestibilities in treatment $P h E$ compared to treatment $P h$. One can assume that the supplemented vitamin $E$ was used as an antioxidant to prevent the susceptible compounds such as unsaturated fatty acids in the diet from oxidation in the digestive tract.

\section{IMPLICATIONS}

The commercially available phytase used in this study was effective in improving the performance results of growing-finishing 
pigs fed diets not supplemented with inorganic phosphorus as well as other macro and micro minerals. This result was brought about by a considerable increase in phosphorus digestibility of the diet. An extra dietary supplementation with $\alpha$-tocopheryl acetate may be recommended in pig diets with microbial phytase inclusion and with a high fatty acid oxidative capacity.

\section{ACKNOWLEDGEMENTS}

The authors wish to thank F. Hoffmann-La Roche LTD, Animal Nutrition Research, Basel, for the financial support, and the Swiss Federal Research Station for Animal Production (RAP), Posieux, and the 'Prüfanstalt des Schweizerischen Verbandes für Mast- und Schlachtleistungsprüfung beim Schwein (MLP)', Sempach, for analytical and technical support.

\section{REFERENCES}

[1] Asghar A., Gray J.I., Miller E.R., Ku P.-K., Booren A.M., Influence of supranutritional vitamin E supplementation in the feed on swine growth performance and deposition in different tissues, J. Sci. Food Agric. 57 (1991) 19-29.

[2] Bieri J.G., Corash L., Hubbard V.S., Medical uses of vitamin E, New Engl. J. Med. 308 (1983) 1063-1067.

13] Cannon J.E., Morgan J.B., Schmidt G.R., Tatum J.D., Sofos J.N., Smith G.C., Delmore R.J., Williams S.N., Growth and fresh meat quality characteristics of pigs supplemented with vitamin E, J. Anim. Sci. 74 (1996) 98-105.

[4] Cromwell G.L., Coffey R.D., Parker G.R., Monegue H.J., Randolph J.H., Efficacy of recombinant-derived phytase in improving the bioavailability of phosphorus in corn-soybean meal diets for pigs, J. Anim. Sei. 73 (1995) 2000-2008.

15] Den Hartog L.A., Huisman J., Thielen W.J.G., Van Schayk G.H.A., Boer H., Van Weerden E.J., The effect of including various structural polysaccharides in pig diets on ileal and faecal digestibility of amino acids and minerals, Livest. Prod. Sci. 18 (1988) 157-170.

[6] Drochner W., The influence of changing amounts of crude fibre and pectic components on precaecal and postileal digestic processes in the growing pig, Adv. Anim. Physiol. Anim. Nutr. 14 (1984) pp. 125.

17] Elmadfa I., Bosse W., Vitamin E: Eigenschaften, Wirkungsweise und therapeutische Bedeutung, Wiss. Verlagsges, Stuttgart, 1985.
[8] Gebert S., Bee G., Pfirter H.P., Wenk C., Phytase and vitamin $E$ in the feed of growing pigs: 1. Influence on growth, mineral digestibility and fatty acids in digesta, J. Anim. Physiol. Anim. Nutr. 81 ( 1998a) 9-19.

[9] Gebert S., Bee G., Pfirter H.P., Wenk C., Effect of dietary phytase and vitamin $\mathrm{E}$ supplementation to a diet high in oxidative capacity on meat and fat quality in pork, in; Effects of microbial phytase and vitamin $E$, in fat supplemented diets for growing pigs and laying hens on performance, nutrient utilization and product stability against oxidative alteration, Diss. ETH No 12563 (1998b) 52-67.

[10] Gifford S.R., Clydesdale F.M., Interactions among calcium, zinc and phytate with three protein sources, J. Food Sci. 55 (1990) 1720-1724.

[11] Hadorn R., Einfluss unterschiedlicher Nahrungsfaserträger (Soja- und Hirseschalen) im Vergleich zu Weizenquellstärke auf die Nährstoffund Energieverwertung von wachsenden Schweinen und Broilern, Diss. ETH Nr. 10946, 1994.

[12] Häuser A., Einfluss von Fett und Tocopherol im Futter sowie von fleischtechnologischen Behandlungen auf die Oxidationsstabilität von Schweinefleisch - Patties, Diss. ETH Nr. 9567, 1991.

[13] Jongbloed A.W., Morz Z., Kemme P.A., The effect of supplementary Aspergillus niger phytase in diets for pigs on concentration and apparent digestibility of dry matter, total phosphorus, and phytic acid in different sections of the alimentary tract, J. Anim. Sci. 70 (1992) 1159-1168.

[14] Marquering B., Westendarp H., Warnke J., Mehr Vitamin E bringt keine Vorteile, DGS - Magazin 8 (1996) 46-48.

[15] Metcalfe L.D., Smith J.F., The rapid preparation of fatty acid esters for gas chromatographic analysis, Anal. Chem. 33 (1961) 363-364.

[16] Mroz Z., Jongbloed A.W., Kemme P.A., Apparent digestibility and retention of nutrients bound to phytate complexes as influenced by microbial phytase and feeding regimen in pigs, J. Anim. Sci. 72 (1994) 126-132.

[17] Pallauf J., Höhler D., Rimbach G., Effekt einer Zulage mikrobieller Phytase zu einer Mais-SojaDiät auf die scheinbare Absorption von $\mathrm{Mg}, \mathrm{Fe}$, $\mathrm{Cu}, \mathrm{Mn}$ und $\mathrm{Zn}$ sowie auf Parameter des Zinkstatus beim Ferkel, J. Anim. Physiol. Anim. Nutr. 68 (1992) 1-9.

[18] Partridge I.G., Studies on digestion and absorption in the intestines of growing pigs. 3. Net movements of mineral nutrients in the digestive tract, Br. J. Nutr. 39 (1978) 527-537.

[19] Prabucki A.L., Rennerova A., Vogtmann H. Wenk C., Schürch A., Die Verwendung von $4 \mathrm{~N}$ HCL-unlöslicher Asche als Indikator zur Bestimmung der Verdaulichkeit. Physiologie der Verdauung. Misc papers II, Landhouwhogeschool, Wageningen, The Netherlands, 1975 
[20] RAP/Swiss Federal Research Station for Animal Production, $\mathrm{Fe} / \mathrm{Mn} / \mathrm{Cu} / \mathrm{Zn}$ im Makrobere ich: Bestimmung in Futtermitteln, Dokumentennummer ME 132020.710, Posieux, Schweiz, 1993.

[21] RAP/Swiss Federal Research Station for Animal Production, Fütterungsempfehlungen und Nährwerttabellen für Schweine. 1. Auflage, in: Boltshauser M., Jost M., Kessler J., Stoll P. (Eds.), Verlag Landwirtschaftliche Lehrmittelzentrale, Zollikofen, Schweiz, 1993.

[22] RAP/Swiss Federal Research Station for Animal Production, Spurenelementaufschluss: Aufschluss der Rohasche zur Analyse der Mineralstoffe im Spurenbereich. Dokumentennummer ME 124010.710, Posieux, Schweiz, 1993.

[23] Rettenmmaier R., Schüep W., Determination of vitamin $\mathrm{A}$ and $\mathrm{E}$ in liver tissue, Int. J. Vitam. Nutr. Res. 62 (1992) 312-317.

[24] Richardson T., Korycka-Dahl M., Lipid Oxidation, Developments in Dairy Chemistry, vol. 2, Applied Science Publishers, London, New York, 1983, pp. 24l-363.

[25] Rodehutscord M., Faust M., Lorenz H,, Digestibility of phosphorus contained in soybean meal, barley, and different varieties of wheat, without and with supplemental phytase fed to pigs and additivity of digestibility in a wheat-soybean meal diet, J. Anim. Physiol. Anim. Nutr. 75 (1996) 40-48.

[26] Schaarmann G., Wirth R., Flachowsky G., Scheinbare Verdaulichkeit und Vitamin E Absorption beim Schwein und Mesch bei erhöhtem Vitamin E - und Ballaststoffgehalt der Diäten, in: Schubert R., Flachowsky G., Bitsch, R. (Eds.), Vitamine und Zusatzstoffe in der Ernährung von Mensch und Tier, 5. Symposium Jena / Thüringen, 1995, pp. 178-182.

[27] Statgraphics plus for Windows 2.1, Statistical Graphics Corporation, Rockville USA, 1995.

[28] Veen W.A.G., Einflussfaktoren auf die Fettverdaulichkeit bei Geflügel und Schweinen, Fat Sci. Technol. 92 (1990) 528-532.

[29] Wenk C., Weiss E., Bee G., Messikommer R., Interactions between a Phytase and a Carbohydrase in a pig diet, in: Enzymes in Animal Nutrition, Proceedings of the lst Symposium, Kartause Ittingen, Switzerland, 1993, pp. 160-164.

[30] Winter E., Über ein neues Verfahren zur Bestimmung und Untersuchung von Fetten in Lebensmitteln, Z. Lebensm. Unters. For. 123 (1963) 205-210. 